\title{
The military versus democracy in Fiji: problems for contemporary political development
}

\section{Abstract for chapter 9}

\section{Author: Stephanie Lawson}

In this chapter, the author's focus is on the notion of 'regime vulnerability' as applied to the civil institutions of government in Fiji, both before and after the 1987 coup. The author considers the past, present and future role of the military, with particular emphasis on its relationship with civilian authority.

The author clarifies 'regime vulnerability', especially in terms of the comparative strength or weakness of civil institutions. She also gives an overview of Fiji's colonial history and legacy before outlining the role of the military in Fiji.

In terms of future directions for politics in Fiji, the author examines the concepts of overt and covert regimes, and concludes by stating that democratic constitutionalist principles are unlikely to prevail in Fiji in the short term.

\section{Keywords}

civil-military relations, colonial government, regime, the state 


\title{
9
}

\section{THE MILITARY VERSUS DEMOCRACY IN FIJI: PROBLEMS FOR CONTEMPORARY POLITICAL DEVELOPMENT}

\author{
Stephanie Lawson
}

Like many former British colonies, Fiji inherited a form of Westminster parliamentary government. The 'parent model' was modified to the extent that it incorporated a number of provisions designed to secure a special position for indigenous Fijians vis-à-vis the Fiji Indian community. This deviation from modern democratic norms was meant to stabilise Fiji's 'plural society' by ensuring equal representation in the House of Representatives for the two major ethnic groups. For the first seventeen years following independence it seemed that this model had achieved broad acceptance by most parts of the polity. During this time, the office of government was held continuously by the Fijian-dominated Alliance Party led by one of Fiji's paramount chiefs, Ratu Sir Kamisese Mara. In April 1987, however, the Alliance Party was defeated at the polls by a coalition, led by Timoci Bavadra, comprising the relatively new multiracial Labour Party and Fiji's oldest political party, the National Federation Party, which had always attracted the bulk of Fiji Indian support. Less than six weeks after the elections, the new government was overthrown by a military coup and Fiji's form of parliamentary democracy followed the path of failure experienced by so many postcolonial states. Both democracy and its corollary model of civil-military relations were shown to have been acceptable to Alliance leaders and supporters, as well as key elements in the military, only so long as the Alliance retained office as government. In other words, those democratic norms associated with the doctrine of constitutionalism and the principle of alternation in government lacked a secure foundation.

The military intervened again some six months later when coup-leader Rabuka ${ }^{1}$

As a lieutenant-colonel, Sitiveni Rabuka was then the third-ranking officer in the Royal Fiji Military Forces. He became commander of the Fiji Military Forces and was promoted to the rank of major-general. 
accused civilian leaders, including his own traditional paramount chiefs, of failing to follow through his initial 'objectives', namely, the absolute entrenchment of 'indigenous rights'. In subsequent developments the 1970 constitution was abrogated, Fiji declared a Republic, a civilian administration installed, and a new constitution promulgated in the name of the 'Sovereign Democratic Republic of Fiji'. The first general elections following these events were held in 1992, and the rigid discriminatory electoral and parliamentary provisions ensured the return of a government sympathetic to the stated objectives of Rabuka's coup. Given this scenario, it might be thought that the conditions for future civilian supremacy - albeit within a traditionalist/nationalist Fijian framework - have been firmly re-established while, conversely, those conditions most conducive to praetorianism have weakened considerably. But this depends ultimately on the strength of the new civilian institutions. These purport to rest on a 'traditional' Fijian foundation of authority, and chiefly leaders have the advantage of being able to evoke powerful symbols of legitimacy. But the appeal of these symbols and the institutions they now support is limited to a minority of the population. Furthermore, the recent history of Fiji suggests that, at the very least, the future role of the Fiji Military Forces will be to act as covert guardian of the 'national interest'. In the terms ordained by Rabuka's 'objectives', this national interest necessarily precludes a return to more democratic constitutional forms which would allow adequate participation in politics by the entire body of citizens both Fijian and Fiji Indian.

This study takes as its primary focus the notion of 'regime vulnerability' as applied to the civil institutions of government in Fiji both before and after the coup. In adopting this approach we shall of course consider the past, present, and future role of the military with particular emphasis on its relationship with civilian authority. As a necessary preface to this study, we must clarify first what is meant by 'regime vulnerability', especially in terms of the comparative strength or weakness of civil institutions.

\section{Regime Vulnerability}

Following its early articulation by Finer (1962), the idea that the level of political culture in a given society (and the concomitant strength of its civil institutions) is decisive for the regime's vulnerability to military intervention has underscored a host of later studies (for example, Huntington 1968; Perlmutter 1981; Rapoport 1982; Luckham 1971; Eide and Thee 1980). And although the general notion has no necessary or exclusive link with the collapse of post-colonial democratic regimes in the Third World, many of the case studies undertaken within this 
context address precisely the 'failure of democracy' problem. Further, Finer's conceptual framework clearly supports the assumption that Western democracies have achieved a 'mature political culture' through which civilian institutions are strongly legitimated, whereas political and social institutions elsewhere are relatively weak and lacking in legitimacy (see Berghahn 1981:69). In much of the literature on Fiji that has burgeoned since the coup, the assumptions underlying Finer's basic proposition have received implicit support. Various justifications offered by Fiji's military leader, and many supporters of his initial intervention and subsequent role in the process of constitutional change, have also served to reinforce the images projected by Finer's claims.

The utility of the concept of regime vulnerability has attracted some criticism, especially in terms of its explanatory and predictive force. Luckham (1971:10), for example, points out that the criteria for determining the strength of civilian institutions assumes, in many cases, precisely that which needs to be explained. He refers to several of the criteria proposed by Finer, and especially to the requirement that there must be 'publicly agreed procedures for the transfer of power' (ibid.:11). Luckham suggests that the coup itself may, in some circumstances, 'become a publicly recognised and quasi-legitimate means for the transfer of power' (1971:11). One implication of this is that the presence of publicly agreed procedures per se does not serve adequately to distinguish 'weak' civil institutions from 'strong' civil institutions. But Finer's basic criterion is rescued from any ambiguity in its application if we simply add the premise that publicly agreed procedures for transferring power from one government to another must exclude any form of military intervention (and this is undoubtedly what Finer meant). It is certainly the case that any democratic method devised for the transfer of power must, by definition, preclude military intervention, for modern democratic theory and practice is founded, inter alia, on strictly constitutionalist principles which deny the legitimacy of force, or the threat of force, in determining succession of government.

Another critic of orthodox regime vulnerability theory, Thompson (1975:459, 466), suggests that hypotheses subscribing to the weakness of governmental institutions as a standing invitation to domestic military intervention are virtually tautological and, further, that overemphasis on the themes which support such hypotheses has obscured the role of the military as a homus politicus in its own right. Four themes are identified by Thompson (1975:460-64). One is that the study of unique historical and cultural legacies provides an essential explanation for present behavior. A second concerns the 'failure of democracy' which is predicated on excessive diversity within the polity, a lack of democratic preconditions, and a general disillusionment when economic improvements lag well 
behind expectations. Another theme extends the second by employing the notion of a political void. This void is created by the absence of traditional loyalties to constitutionalist forms which leads in turn to institutional atrophy. The military, acting as a Hobbesian trump, is drawn into the void. Finally, the 'disjointed system' theme concentrates on the lack of authoritative formulae for the resolution of conflict. In this situation, rival groups seeking to establish their own primacy continually undermine that sense of community essential to the structural development of central, legitimate institutions. In the absence of such institutional development - and depending on the evolutionary stage of class relations - the military may be pulled into a praetorian role of conservative guardianship. Thompson (1975:466) comes to the unremarkable conclusion that all these themes 'share a common image of the military coup: weak political systems pull the military into action'. A key purpose of Thompson's review of these themes, however, is not to demonstrate the obvious, but to construct an alternative image of the location of the military within the state. This location is described by Thompson (1975:486-87) from a praetorian perspective insofar as the military is perceived to be an integral part of the political system rather than an entity which operates outside it. This has some important implications for the present study, to which we shall return at a later point. For the present it is necessary to clarify the conceptual issues further by examining the notion of 'regime' itself.

In most of the literature on military intervention, the terms 'regime' and 'government' are used interchangeably. This is perhaps because the overthrow of a government generally entails, ipso facto, the overthrow of the regime. Furthermore, most writers in the area are content to utilise the concept of 'regime' simply as a term to attach to 'civil' or 'military'. But although regime and government are closely related, they are not the same thing, and it is important to understand the basic analytical distinctions between them. This is especially so in the case of Fiji when we come to consider the notion of legitimacy and how it operates at different levels. Also vital to the study of political structures and their legitimacy is, rather obviously, the state. Control of the state apparatus is the focal issue in cases of military intervention, and associated ideological contestations revolving around nationalism are usually linked directly with this quest for control. The relationships between state, regime, and government are complex, and to deal with these properly would require much more scope than is available here. In order to at least differentiate these structures for the purpose of the present discussion, it must suffice to say that the state itself is the locus of political power while the concept of regime is concerned with how, and by whom, that power is exercised. In other words, 'regime' is concerned with the form of rule (see Chazan et al. 1988; Lawson 1993). 
Governments are awarded management or control of the state apparatus in accordance with the norms and principles of the regime which are embodied, for practical purposes, in certain rules and procedures. Governments derive much of their legitimacy as controllers or managers of the state apparatus from the norms and rules of the regime. These are generally embodied in a constitution which sets out those 'publicly agreed procedures for the transfer of power'. All this is implicit in the democratic doctrine of constitutionalism. At another level, however, the regime itself requires legitimacy. And where this is weakly supported, it follows that the regime - and governments formed under it - are vulnerable to challenges which, in the particular case we are dealing with here, came in the form of military intervention. The point in setting up this rather formalised schema here is to clarify the point that 'regime vulnerability' entails more than just 'government vulnerability'.

In the case of Fiji, both the government that was overthrown, and the regime under which it was formed, were regarded by the military and other opponents of the government as lacking an essential legitimacy. This is clearly evident in the justifications surrounding the coup and the subsequent process of constitutional change. But to understand the problems associated with political legitimacy, it is important to investigate the historical context which gave rise to the civil institutions of post-colonial Fiji, and the specific factors which contributed to their essential 'weakness'. Through this it will be seen that the various hypotheses concerning regime vulnerability are indeed relevant, not only to the analysis of the original coup in Fiji, but to the future of civil-military relations there.

\section{Fiji's Colonial Legacy ${ }^{2}$}

British colonial rule was established in Fiji in 1874 following a period of internal strife occasioned partly by the activities of European settlers and traders in the eastern regions of the island group. It was in this region, too, that the most powerful of the Fijian confederacies were located and rivalries between leading chiefs there exacerbated the general deterioration in domestic politics that followed European contact. The British government was to some extent a reluctant coloniser at this time. The further extension of empire in the remote Pacific promised little in the way of economic rewards and only the potential for strategic advantage offered any return on their 'investment'. The general policy towards the new colony of Fiji, then, was that its administration should pose as small a financial burden to Whitehall as possible and, ideally, that it should be economically 
self-sufficient. Fiji's first substantive governor, Sir Arthur Hamilton Gordon, therefore set about implementing a set of policies which were directed not only towards establishing a solid financial base for the new colony, but which reflected also a relatively new approach to the 'management' of colonial subjects. The strategies adopted by Gordon to secure these objectives were decisive for the later development of politics in Fiji.

The first of these strategies concerned 'native policy' and this was aimed partly at making the colonial experience for Fijians an exception to the dismal history of colonised people in other parts of the empire. One of the measures introduced was the reservation of those Fijian lands not already 'legally' alienated to white settlers, and the prohibition of any further land alienation. Although this measure was sound in principle, the method by which land tenure was assigned on the basis of certain kinship groups, and which remains in place to this day, imposed a uniformity and inflexibility that bore little resemblance to pre-colonial Fijian practices. The land tenure system has since served as a serious impediment to the efficient and equitable utilisation of land resources amongst Fijians. In addition, the bureaucratic structures relating to the administration of land, including the leasing of agricultural land to both Fijian and Fiji Indian tenants, have creamed off much of the income from leases. A substantial proportion of the remaining funds is distributed to chiefs. Fijian 'commoners' receive few direct benefits from the leasing of their lands, and this was one of the issues that the Labour/NFP coalition government had placed on the political agenda. Concern for the security of indigenous land rights was made a focal issue by the Alliance Party during the 1987 elections and figured prominently in the rhetoric surrounding justification of the coup. It is therefore important to note that the 1970 constitution of independent Fiji provided triple entrenchment of Fijian rights with respect to land and other customary entitlements.

A second strategy for securing the principles of the new enlightened native policy was the establishment of a system of indirect rule. This was achieved by taking the relatively authoritarian chiefly structures of control which characterised socio-political organisation in the eastern regions as the basis for the system, and imposing these uniformly over the entire island group. In addition, selective recruitment to the colonial bureaucracy from amongst easterners served to marginalise Fijians from other regions. One consequence of this was that eastern chiefs achieved much greater prominence within the colonial regime. As political institutions evolved from an initially rigid crown colony system to something resembling responsible government in the pre-independence period, eastern chiefs retained their political prominence and reinforced their prospects for future control through the formation of the Alliance Party. This underscored exclusive 
claims to political legitimacy by eastern chiefs vis-à-vis any other political group in Fiji.

The third strategy employed by the colonial administration involved balancing the policy of 'native protection' with the requirement of financial self-sufficiency. The use of Fijian labour in the emerging plantation economy was viewed as detrimental to the traditional Fijian way of life and Governor Gordon looked immediately to the Indian sub-continent from which other British colonies had successfully recruited their 'helots of empire'. The first Indian indentured laborers arrived in Fiji in 1879 and by the time the system was abolished in 1916, Fiji had acquired a substantial, and permanent, population of Fiji Indians whose descendants now comprise around 46 per cent of the total population. This created what is commonly described as Fiji's 'plural society' in which the two major ethnic groups are perceived as constituting monolithic entities in a two-sided contest for political power. This perception is largely responsible for popular conceptions concerning the essentially 'racial' cause of the May 1987 coup. And although most academic commentators - with the notable exception of Scarr (1988) - have evinced a complex array of causes which point to the salience of other decisive factors (see, for example, Lawson 1991; Ewins 1993), the general perception of contemporary developments in Fiji remains fixed firmly within a racially-oriented paradigm.

Another aspect of Fiji's colonial legacy which is closely related to the developments outlined above, and with the issue of eastern chiefly legitimacy, concerns the doctrine of Fijian 'paramountcy of interests'. This doctrine upholds the supremacy of Fijian interests over and above the interests of any other racial or ethnic group in Fiji. It developed as a colonial version of an indigenous rights charter which, although never formally codified, developed into a powerful orthodoxy. The doctrine's initial purpose was to underscore the early policies instituted by Gordon. As we have seen, these had been designed largely to protect Fijians from European settler exploitation. But as the Fiji Indian community grew, the doctrine was employed by European and Fijian leaders alike as a counter to the Fiji Indians' quest for social, political, and economic rights. It became, in effect, a forceful rhetorical weapon in a war of subjugation which was at first prosecuted most vigorously by the small but influential European commercial elite concerned to retain their own privileged position in the colony. This enabled Europeans, inter alia, to represent themselves as champions of the Fijian people and guardians of their interests. For their part, Fijian political leaders, who were drawn almost exclusively from chiefly ranks (with easterners predominating), took up the same rhetorical stance and denounced Fiji Indian claims for equal political rights as anathema to the interests of the Fijians as a whole.

This of course raises questions as to the precise nature of the interests of each 
'group', and especially whether the interests of Fijian chiefs are automatically consonant with those of commoners. One must question also the notion that any interests espoused by the eastern chiefly elite necessarily accord with the interests of Fijians in other regions. These issues will be considered later in the context of contemporary politics. For the moment it is important to note that the doctrine of Fijian paramountcy developed a political salience which went far beyond its original utility. We have seen already that Fijian rights relating to land and other resources were well established in the early colonial period and firmly secured through the 1970 constitution. But the general themes of the doctrine, combined with the spectre of an 'Indian land-grab', continued to be pursued by Alliance and other nationalist leaders at the level of political rhetoric (and invective) in post-independence electoral campaigns. With respect to the Alliance and the eastern chiefly elite, this served the instrumental purpose of uniting the bulk of the Fijian electorate behind their leadership in direct opposition to Fiji Indians. Furthermore, the Alliance presented its leadership as the embodiment of all that is distinctively, traditionally, and legitimately 'Fijian'.

Both the formal political institutions and the party system that emerged in the late colonial period reflected these earlier developments, as did the 1970 constitution of independent Fiji. Apart from recognising and securing the special rights and interests of indigenous Fijians, the constitution provided for a complex system of communal representation through which equal numbers of Fiji Indians and Fijians were returned as members of the House of Representatives. In addition, eight 'general' members were to be returned as representatives of 'other races'. Most of these were of European descent and were aligned politically with the Alliance Party. This meant that despite formal parity of representation for Fiji Indians, the racial allocation of seats gave an immediate electoral advantage to the Alliance and, indeed, seemed designed to ensure that the Alliance would continue indefinitely in office. Viewed in this light, the 1970 constitution cannot be seen as an instrument for securing the practice of democratic politics beyond the formal superficialities of parliamentary government. More specifically, the principle of alternation in government, which is an essential hallmark of modern representative democracy, was undermined to the extent that the legitimacy of the opposition party as a potential or actual government was not recognised by the Alliance leadership.

Continued Alliance dominance, however, depended on their maintaining a solid electoral base amongst Fijians. Any intra-Fijian disunity would necessarily erode this base and leave the Alliance vulnerable to electoral defeat, and this is precisely what happened in the elections of 1987. Although the Labour/NFP coalition was unable to attract more than around 10 per cent of the overall Fijian vote, it was 
able to muster sufficient Fijian and 'other races' support in several crucial urban and peri-urban constituencies. This, combined with a further slippage of Alliance support to minor parties and independents as well as a significant level of Fijian abstention from voting, gave the coalition a majority of seats. But the events which followed the formation of the new government indicated clearly the extent to which it lacked that widespread legitimacy essential to the principle of alternation in government. Despite Ratu Mara's formal concession of defeat, Alliance members boycotted the opening of parliament and several became involved in the activities of the extremist Taukei movement - a nationalist Fijian group which emerged in the aftermath of the Alliance's defeat and which resolved to bring down the new government. Mara maintained a public silence which was seen to implicitly endorse their activities. And when the army intervened less than six weeks after the elections, Mara was amongst the first to join the initial administration set up by coup-leader Rabuka.

The point of the foregoing discussion has been to highlight a number of important factors which, taken together, served to undermine the legitimacy of the political institutions established by the 1970 constitution, thereby rendering them 'weak' and vulnerable to attack. This vulnerability operated at two levels. First, it is evident that any government other than the Alliance could be portrayed rhetorically as a significant threat to Fijian rights - a logical corollary to the idea that only the Alliance could guarantee the rights and interests of all Fijians. These ideas were taken much further than the original doctrine of paramountcy of interests implied, for this was basically concerned with the protection of lands and customary matters which remained constitutionally entrenched no matter which government was in power. In turn, this doctrine was invoked to deny virtually any political legitimacy to Fiji Indians and, it must be added, to those dissident Fijians who formed the backbone of the Fiji Labour Party. Put simply, the legitimacy of the new government was weakly supported, and therefore vulnerable to challenge, since it was opposed by a dominant political discourse which had succeeded in elevating a particular group of Fijians to a position of almost exclusive authority.

The second aspect of vulnerability operated at the regime level. Although the constitution was, arguably, designed to entrench a one-party dominant system, it nonetheless supported formally all those democratic constitutionalist principles associated with the notion that no one political group is entitled to lay exclusive claims to legitimacy and, through this, control of the state apparatus. It is clearly evident that neither the Alliance Party nor the military accepted the legitimacy of a regime which allowed succession of government according to democratic constitutionalist norms and principles. In other words, those "publicly agreed 
procedures for the transfer of power' provided by the constitution were, when put to the test, shown to lack universal acceptance. This view has been reinforced by the promulgation of the new republican constitution, the rules of which seek to prevent the possibility of any such succession occurring again.

The new constitutional order, however, is one which undoubtedly lacks the support of a majority of the population in Fiji. Although this has not been tested by way of a referendum, one can assert fairly confidently that most Fiji Indians would regard it as illegitimate. And since the new electoral provisions for Fijians are grossly biased in favour of the eastern provinces, it is not unreasonable to assume that Fijians on the main island of Viti Levu will resent and resist eastern dominance - especially those in the west whose history of dissidence suggests more than a little reluctance to endorse eastern legitimacy. In addition, the allocation of Fijian seats is weighted most heavily against the more 'progressive' urban Fijians who make up around one third of the Fijian population but who have been awarded only five of the thirty-seven Fijian seats. Taken together, these factors suggest weak support for the new regime and, as a consequence, for any government formed under its provisions. Whether this will promote susceptibility to further military intervention, or at least a praetorian role for the military, is another question, and one best addressed now by reference to the development of Fiji's military forces and its role in contemporary politics.

\section{The Military in Fiji}

The origins and development of Fiji's military forces reflect clearly the sociopolitical dimensions of Fiji's pre-colonial and colonial history. When Governor Gordon took over the administration of the colony, there was already a small military force known as the Royal Army, which had been used by Fiji's leading eastern chief, Cakobau, and his British supporters in an attempt to control the central and western regions. Gordon continued to employ this unit for its original purpose of subjugation, thereby reinforcing eastern chiefly authority and interests. Following the relative success of these early pacification operations, the unit (which had meanwhile been renamed the Armed Native Constabulary) was amalgamated with the police of the Fiji Constabulary. In the early 1920s, further 'pacification' operations were conducted against striking Indian workers (Sanday 1989:3).

From the beginning, then, the armed forces in Fiji were utilised largely for coercing troublesome groups in the interests of internal political stability. This early emphasis, and the identification of 'troublesome' with dissident western Fijians and Fiji Indians, saw the already dominant position of 'loyal' easterners 
further reinforced through selective recruitment to the constabulary - and later to the regular armed forces. This is a very clear manifestation of Enloe's (1980: 16) conception of 'security mapping' where the ethnically-determined basis of recruitment involves convenient geographical concentrations. Further, it is evident that the early orientation of state security in Fiji was strongly biased towards 'the maintenance of congenial domestic class and ethnic patterns of order' (Enloe 1980:14).

The later development of Fiji's military as an entity distinct from the police, and as a standing army in its own right, was given its major impetus by the call of empire. Two world wars and the Malayan Emergency saw troops from Fiji serve monarch and empire in defence, presumably, of 'democracy'. Back home, however, little progress had been made with respect to democratic rights for Fiji Indians, and this had a direct effect on military recruitment for World War II. Many Fiji Indian grievances had been centred on the issue of parity of political rights and status with Europeans (not Fijians). When the war broke out, the sense of inequitable political treatment was further exacerbated by differential pay rates for Fiji Indians and Europeans in the army and most Fiji Indians declined to volunteer for service for this reason. The only Indian platoon in the army, which had been formed in 1934 despite some resistance on the part of the colonial administration and the chiefs, was disbanded (Sharma 1990:63). This not only strengthened the apparent political divide between Fiji Indians and the other communities, but served also to consolidate the army as an essentially Fijian institution.

At the time of the coup in 1987 the composition of the Royal Fiji Military Forces (RFMF) was 98 per cent Fijian. They were led by Brigadier Ratu Epeli Nailatikau, a high chief from the east and also son-in-law of Prime Minister Mara. Although many able commoners had been admitted to high-ranking positions, including the then third-ranking officer Lieutenant-Colonel Sitiveni Rabuka, those from eastern chiefly families were disproportionately represented in the officer corps. Commoners like Rabuka, who had achieved high rank, were also drawn in disproportionate numbers from the east. Saffu (1990:162) suggests that the extent of eastern dominance in the RFMF, together with the historical factors outlined earlier, was responsible for the development of a 'traditional-aristocratic' pattern of civil-military relations which operated alongside the liberal-democratic pattern throughout the independence period until May 1987. Saffu (1990:159) argues also that both patterns were compatible with civilian political supremacy until the electoral victory of the coalition when the liberal-democratic pattern was abrogated abruptly 'because it did not guarantee control of the state by chiefs and other traditionalists'. This is consistent with the arguments put forward earlier 
concerning the lack of legitimacy accorded both to the coalition and to the regime under which the new government was formed.

Another aspect of the analysis, and one which is vital to future developments in civil-military relations in Fiji, concerns the prospects for the traditional-aristocratic model. Saffu (1990:159) draws on Nordlinger's (1977) work in identifying the core features of the model. The most basic indicator supporting civilian supremacy is a strong identification of social and political values between civilian and military leaders in an essentially 'pre-democratic' system. Civilian leaders are regarded as legitimate insofar as they are part of the same social network of aristocratic families that provides military leaders. Sanday (1991:253) says that this pattern was reflected in a pervasive belief amongst indigenous Fijians that political power was the exclusive preserve of the chiefs. The role of the military in post-coup Fiji seemed to point to a continuation of the traditional-aristocratic pattern.

In the immediate aftermath of the coup, Rabuka established a sixteen-member Council of Ministers comprising eleven Alliance parliamentarians (including Mara) and four members of the nationalist Taukei movement. Rabuka himself, as head of this body, was the only military member. This was replaced shortly afterwards with an eighteen-member Council of Advisors which, as a necessary façade for at least qualified domestic and international acceptance, included three Fiji Indians as well as Bavadra. Rabuka, however, remained a leading member. The new arrangements, and of course the coup itself, were endorsed wholeheartedly by the Council of Chiefs who had resolved that the military should be asked to review the 1970 constitution to ensure that Fijians were guaranteed control of government at all times (Lal 1988:87). And Rabuka's ambitions for the military were expressed unambiguously in numerous statements on its future role, including an assertion that the military would remain an integral part of any kind of political system, irrespective of what form it might take (Lal 1988:113).

In the meantime, some rapprochement had been reached between the civilian actors in the play of negotiations. A degree of moderation had started to prevail as Taukeist leaders, and Rabuka himself, became increasingly marginalised in the process of negotiations which led eventually to the 'Deuba Accord' - an agreement under which both the Alliance and the deposed coalition were to participate on equal terms in a caretaker government under the governor-general, Ratu Sir Penaia Ganilau (Robertson and Tamanisau 1988:138). Although Rabuka had apparently agreed to support the new accord, it is evident that his intentions were otherwise. Two hours before the governor-general was scheduled to inform the nation of the new caretaker government, Rabuka led a second coup to enforce his original 'objectives'. Within days Rabuka announced the complete abroga- 
tion of the 1970 constitution and declared himself head of a republican government (Robertson and Tamanisau 1988:142). But Rabuka's position as head of the republic, although supported by military force, was untenable politically. Leaving international opinion aside, Rabuka could not, as a commoner, hope to legitimate himself as leader at that time. In his own rationale for both coups, Rabuka had consistently promoted the paramount importance of Fijian 'tradition' and the virtually sacrosanct political position of chiefs in this context. So powerful had the rhetoric about chiefly authority become that it left Rabuka in the position of being unable to command personally the symbolic resources associated with political legitimacy in Fiji. In his own words, Rabuka had claimed that the military was 'trying to protect the chiefs and their people' and, further, that it was the 'duty of the warrior tribe to protect the chief' (quoted in Norton 1990:139).

In the wake of the second coup, then, the eastern chiefly elite returned once more to the helm of government, replacing the Taukeist council which Rabuka had installed as an interim measure. Rabuka continued for a time as a member of the ministry but was later forced to 'return to barracks' at the behest of Mara who had given him the choice of resigning either from the military, or from the government. In August 1991, however, Rabuka decided to quit the military in order to pursue a political career, and returned to the post of co-deputy prime minister and minister for Home Affairs in the interim government. Ganilau continued to occupy the position of president while Mara remained prime minister until the 1992 elections. Rabuka's political ambitions, however, were well known and his decision to enter civilian politics as a leading member of the Fijian Political Party (which was formed with the backing of the leading chiefs) was a clear enough indication that he would be a contender for the prime ministership in the elections. Given the lack of suitable chiefly successors to Mara in the FPP, as well as the emergence of several rival Fijian parties, the longer-term outlook for stable government under the chiefly establishment was beginning to look more uncertain. This brings us back to the question, posed at the beginning, concerning the prospects for continuing civilian supremacy and whether the new regime is itself vulnerable to some kind of intervention.

\section{Future Prospects}

In looking at possible future directions for politics in Fiji, we must again consider the notion of regime vulnerability and, in this context, examine also the concepts of overt and covert regimes. In the earlier discussion of the 1970-1987 period, it was evident that although the liberal-democratic framework operated 
at a superficial level as an 'overt' regime, there was at the same time a stronger 'covert' regime operating through traditionalist conceptions of legitimacy. But it took a change of government under the democratic provisions of the constitution to reveal the relative strength - or weakness - of each of these. Following from this, it is logical to depict the liberal-democratic pattern of civil-military relations during the same period as an overt but weakly supported model, whereas the traditional-aristocratic pattern operated at a covert level, but was more strongly supported by the same traditionalist legitimator. The coup of May 1987, then, can be viewed not only as an act of intervention for the purpose of destroying the liberal-democratic façade, but also as an exercise in regime maintenance insofar as it restored the eastern chiefly elite to power - but this time as the overt regime.

The traditionalist regime is now supported formally (and overtly) by a constitution which does little to disguise its essentially undemocratic character. As suggested earlier, however, it lacks the support of a majority of the population, especially as it is explicitly designed to relegate the substantial population of Fiji Indians to electoral irrelevance. In addition, it discriminates heavily against urban Fijians, as well as those from the central and western regions, in favour of the eastern provinces. It is primarily for these reasons that the new regime may, in the final analysis, carry within it the seeds of its own destruction. Far from keeping the indigenous Fijians united in opposition to Fiji Indians, the new constitution is much more likely to serve as an instrument for its political fracture. How long this process may take depends on too many variables for any certain answer to be given. But on any reasonable assessment, the future stability of the chiefly regime must be in doubt - an assessment which has obvious implications for the role of the military. For whatever happens in the arena of civil politics, the military has established itself in a guardian role. In the terms expressed by Luckham (1971:27), the military now has a strong ideological disposition towards regarding itself as the 'Platonic guardian' of the national interest. This points to the continuation of a covert military regime operating beneath the level of the overt chiefly/traditionalist regime. And the praetorian character of this development does indeed suggest that the military in Fiji has become a homus politicus in its own right.

\section{Conclusion}

Whatever specific pattern of civil-military relations emerges in Fiji, it can be said with some certainty that democratic constitutionalist principles are unlikely to prevail in the shorter term. Despite the high-sounding title assigned to the new 
republic, there is no commitment on the part of either chiefly or military leaders in support of these principles. Indeed, much of their traditionalist rhetoric since the coup has been directed explicitly against the 'alien' concepts associated with democratic politics (see especially Dean and Ritova 1988). The logical foundations of the traditionalist view, and the ideology supporting it, have been dealt with critically elsewhere (see Lawson 1990a and 1990b). But whatever claims can be mounted against the logical and ethical bases of political legitimacy in contemporary Fiji, the strength of the prevailing orthodoxies lends sufficient rhetorical force to arguments countering both domestic and external pressures for 'democratisation'. The efficacy of this rhetoric is further strengthened by appeals to the slogan, increasingly popular in international discourse, of 'indigenous rights'. In addition, there is a pervasive belief that 'plural societies' are incapable of sustaining peaceful democratic politics, and can only be managed effectively through relatively authoritarian institutions (see Lawson 1990a). This means that both the military and the current civilian regime have escaped much of the international invective that might otherwise have been directed against the constitutional entrenchment of a system of political apartheid.

Most importantly, it needs to be emphasised that the homus politicus role of the military in Fiji is incompatible with any notion of civilian supremacy. It is especially contrary to the democratic principles embodied in the doctrine of constitutionalism. In other words, if the military becomes a de facto part of the political system insofar as it plays a covert role in determining political leadership, it can no longer be considered the apolitical institution that democratic theory demands. Finally, the effective guardianship of Fiji's 'national interest' by the military betrays an essential weakness in the political culture that has sustained the chauvinistic assertion of 'indigenous rights'. For wherever the threat of force is a necessary condition for maintaining a particular political order, it follows that the order itself lacks the degree of legitimacy required for long-term stability.

\section{Postscript}

The original version of this chapter was written before the general elections of 1992 - the first held after the 1987 coup. There has since been another round of elections in 1994, occasioned by the failure of Rabuka's government to have the budget passed. The text has been modified slightly to take account of these events, but it is worth elaborating a few further points. The 1992 elections held some surprises for those expecting that the 'party of the chiefs' would make a clean sweep of the Fijian seats. Under the leadership of Rabuka, who succeeded in 
replacing Mara as the effective leader of the Fijian party on the latter's retirement, the party (officially called the Soqosoqo ni Vakavulewa ni Taukei or SVT) failed to gain an absolute majority of seats in the House of Representatives. Seven of the Fijian seats went to opposing Fijian parties and independents. The Fiji Indian seats were fairly evenly divided between Labour and the National Federation Party, while the General Voters' Party (which is basically supportive of the SVT, although not necessarily of Rabuka himself), won all five of the General Voters' seats. Rabuka subsequently secured sufficient support from other parties and independents to gain the president's endorsement as prime minister. Rabuka's SVT government, however, lasted just over eighteen months before it fell. This was precipitated by the defection of seven SVT ministers, and followed a period of intense dissent within the government's ranks. Rabuka's party was returned at the next elections with the same majority, and again managed to put together a coalition, but the overall result confirmed that intra-Fijian disunity has become an important factor in current politics. Both elections have shown that the chiefly establishment has been sidelined to some extent in terms of electoral office, but their constitutional powers and prestige remain significant, as does the rhetoric of chiefly traditions. 